\title{
Aktivitas Sosial Masyarakat Kampung Pelangi Banjarbaru Sebagai Sumber Belajar IPS
}

\author{
Rusli $^{1}$, Bambang Subiyakto ${ }^{2}$, Muhammad Adhitya Hidayat Putra ${ }^{3}$ \\ Program Studi Pendidikan IPS, FKIP, Universitas Lambung Mangkurat \\ Email: rusli0017@gmail.com¹, bambangsb@ulm.ac.id ${ }^{2}$, adhitya.hidayat@ulm.ac.id²
}

\begin{abstract}
Abstrak
Persoalan pada pembelajaran saat ini adalah tuntutan kurikulum yang kompleks sehingga menuntut kreativitas guru untuk memanfaatkan sumber belajar kontektual sedangkan sumber belajar IPS yang ada dan dimanfaatkan guru selama ini hanya fokus dikembangkan pada aspek kognitif. Gejala ini berdampak pada pandangan peserta didik dan masyarakat terhadap pembelajaran IPS, bahwa pembelajaran IPS hanya menghafal fakta dan konsep seharusnya pembelajaran IPS bisa dibuat menyenangkan dengan memasukkan sumber belajar yang ada di sekitar peserta didik. Penelitian ini bertujuan untuk mendeskripsikan Aktivitas Sosial Masyarakat Kampung Pelangi Banjarbaru yang kemudian dijadikan Sebagai Sumber belajar IPS. Pendekatan penelitian yang digunakan adalah pendekatan kualitatif dan metode deskriptif dengan pengumpulan data melalui observasi, wawancara, dan dokumentasi. Analisis data melalui reduksi data, penyajian data, dan verifikasi. Uji keabsahan data melalui triangulasi sumber, teknik, dan waktu, member check, dan perpanjangan pengamatan. Hasil penelitian ini menjelaskan beberapa bentuk aktivitas sosial yang ada di kampung pelangi Banjarbaru. Bentuk aktivitas tersebut yaitu, kebersihan lingkungan, pelatihan keterampilan wanita, bakti sosial dan arisan yasinan. Bentuk aktivitas sosial ini kemudian dimanfaatkan sebagai sumber belajar IPS yang kontekstual, dengan sumber belajar yang kontekstual diharapkan peserta didik dapat dengan mudah memahami materi pembelajaran yang diberikan oleh guru, sehingga pandangan tentang pembelajaran IPS yang hanya menghafal berubah dengan adanya sumber belajar yang kontekstual.
\end{abstract}

Kata Kunci: Masyarakat, Aktivitas Sosial, Sumber Belajar IPS

\section{Abstract}

The problem in learning today is the demands of a complex curriculum that demands the creativity of teachers to utilize contextual learning resources while the existing IPS learning resources and utilized by teachers so far only focus on developing cognitive aspects. These symptoms have an impact on the views of learners and the community towards social studies learning, that ips learning only memorizes facts and concepts should be made fun by including learning resources that exist around the learners. This study aims to describe the Social Activities of the Community of rainbow village of Banjarbaru which is then used as a source of social studies. The research approach used is qualitative approach and descriptive method by data collection through observation, interview, and documentation. Data analysis through data reduction, data presentation, and verification. Test the validity of data through source triangulation, technique, and time, member check, and extension of observation. The results of this study explain some forms of social activities in Banjarbaru rainbow village. The forms of activity are, environmental hygiene, women's skills training, social service and arisan yasinan. This form of social activity is then used as a contextual source of social science learning, with contextual learning resources it is expected that learners can easily understand the learning materials provided by teachers, so that the view of social science learning that only memorizes changes with the existence of contextual learning resources.

Keywords: Community, Social Activities, Social Studies Resources. 


\section{PENDAHULUAN}

Pendidikan IPS diharapkan mampu memberikan sumber-sumber lokal untuk dijadikan sumber belajar, pada dasarnya sumber lokal akan memberikan The problem in learning today is the demand for a complex curriculum that demands teacher creativity to take advantage of contextual learning keunggulan berwawasan pengetahuan sosial di masyarakat (Ersis, 2018). Hal ini sejalan dengan tujuan kurikulum 2013 yang menekankan pada dimensi pedagogik modern dalam pembelajaran, yaitu menggunakan pendekatan ilmiah dalam implementasinya (Kemendikbud, 2016), sedangkan yang terjadi di lapangan ketersediaan sumber belajar yang sesuai dengan tuntutan kurikulum kurang, karena sumber belajar yang dapat dimanfaatkan berupa buku teks dan sumber lain dari internet padahal pendidikan IPS bertujuan untuk memajukan pemahaman, keterampilan, dan tingkah laku berdasarkan nilai-nilai masyarakat dan bangsa sehingga peserta didik ikut bagian kelompok negara cinta damai (Putra, 2019). Demikian peserta didik berupaya untuk menghasilkan kelebihan dalam menguasai pemahaman dan interaksi dalam bidang yang akan dipelajarinya.

Pembelajaran yang kontekstual dalam kehidupan masyarakat tidak terlepas dari berbagai aktivitas sehari-hari, masyarakat dapat dikatakan sebagai suatu organisasi manusia yang saling memiliki keterkaitan satu sama lain sebagaimana pembelajaran bermakna (meaningfull) merupakan proses pembelajaran yang mengaitkan antara konsep dengan pengetahuan yang dimiliki peserta didik dari lingkungan sekitarnya (Subiyakto et al., 2018). Sehingga peserta didik lebih jelas dan memahami materi yang disampaikan saat proses pembelajaran (Sa'roni, 2013). Sumber belajar yang kontekstual dapat diperoleh darimana saja. Asal itu menunjang dan mempermudah peserta didik dalam memahami materi pelajaran sehingga mencapai tujuan pembelajaran yang ingin dicapai.

Sumber belajar meliputi segala hal dan memiliki cakupan yang luas. Artinya tidak memiliki batasan tidak hanya orang, alat, bahan, dan lingkungan, melainkan segala sesuatu yang bisa memberikan pengetahuan terhadap peserta didik (Abbas et al., 2017). Senada dengan penjelasan Setiyani, sumber belajar merupakan segala sesuatu yang dapat dimanfaatkan oleh guru, baik berbentuk terpisah ataupun gabungan yang semua itu diperuntukan pada proses belajar mengajar dengan tujuan untuk meningkatkan keefektivitasan dan efisiensi tujuan pembelajaran (Setiadi, 2016). Dengan demikian, sumber belajar dapat ditemui di lingkungan yang dapat menunjang pembelajaran oleh karena itu sumber belajar dapat memanfaatkan lingkungan tempat tinggal peserta didik sebagai sumber belajar, misalkan dengan membawa dari tiruan lingkungan ke kelas (Astuti, 2011). Penjelasan diatas memberikan keleluasaan bagi peneliti untuk mengeksplorasi sumber belajar yang ada di sekitar peserta didik yang bisa dimanfaatkan untuk menunjang proses pembelajaran. Satu diantaranya adalah aktivitas sosial masyarakat kampung pelangi Banjarbaru.

Sebagaimana kampung pelangi terus diupayakan menjadi kawasan wisata dengan mewujudkan Sapta Pesona, sehingga terus diadakan aksi gotong royong untuk membersihkan lokasi sehingga menumbuhkan kesadaran masyarakat untuk menjaga lokasi wisata. Berkaitan pada pelaksanaan di Kampung Pelangi Kelurahan Kemuning ini terlihat bagaimana aktivitas sosial masyarakat dalam kesehariannya yang mengandung aktivitas yang positif, hal ini dapat dikaitkan dalam pembelajaran terkait interaksi antar manusia dengan lingkungannya. Aktivitas itulah yang bisa dijadikan suatu bahan sumber belajar yang dapat diterapkan langsung ke peserta didik.

Oleh karena itu, menanamkan jiwa sosial kepada peserta didik akan sangat membantu jika dilakukan satu sama lainnya, baik dalam lingkungan sekolah ataupun masyarakat tidak terlepas dalam mata pelajaran IPS yang dijadikan sumber belajar (Subiyakto \& Mutiani, 2019; Subiyakto et al., 2020). Aktivitas sosial masyarakat kampung pelangi tersebut kemudian dapat diajarkan ke peserta 
didik seperti halnya penelitian yang dilakukan oleh Khozinatus Saada (2014) dengan judul Pemanfaatan lingkungan sekitar sebagai sumber belajar pada mata pelajaran IImu Pengetahuan Sosial siswa kelas IV Madrasah Ibtidaiyah Yakti Kebonagung, Tegalrejo, Magelang. Hasil dari penelitiannya dapat meningkatkan motivasi dan hasil belajar peserta didik, menambah pengalaman belajar peserta didik serta menumbuhkan sikap dan karakter peserta didik menjadi lebih baik, berbeda dengan penelitian ini yang bertujuan untuk mengetahui aktivitas sosial yang ada di masyarakat Kampung Pelangi dan dimuat dalam pembelajaran sebagai sumber belajar.

\section{METODE PENELITIAN}

Pendekatan penelitian yang digunakan yakni pendekatan kualitatif dengan metode deskripsi. Pendekatan kualitatif untuk mendeskripsikan tentang bentuk aktivitas sosial yang terjadi di lingkungan masyarakat kampung pelangi Banjarbaru sebagai sumber belajar IPS. Pengumpulan data yang dilakukan yaitu observasi, wawancara, dan dokumentasi. Dalam wawancara penelitian ini dilakukan terbagi menjadi dua, yaitu pada pihak akademisi dan masyarakat. Pihak akademisi seperti guru. Sedangkan dokumentasi berupa catatan yang menunjang untuk penelitian dan ditemukan pada subjek penelitian, dan rekaman hasil wawancara terhadap narasumber.

Teknik analisis data peneliti menggunakan tiga tahapan. Pertama reduksi data, mereduksi data berarti merangkum, memilih hal-hal yang pokok, memfokuskan pada hal-hal yang penting utamanya sesuai dengan apa yang ingin diteliti seperti bentuk aktivitas masyarakat kampung pelangi. Kedua penyajian data (display), data yang diperoleh kemudian disajikan dalam bentuk deskripsi dan tabel matrik, kemudian diintegrasikan dengan tema pelajaran yakni bentuk-bentuk aktivitas sosial. Ketiga verifikasi, yakni mengkonfirmasi kebenaran dari data yang di rangkum dan dipilih dengan data yang disajikan (Sugiyono, 2014).

Keabsahan data dilakukan melalui tiga tahapan. Pertama triangulasi, pada tahap triangulasi dibagi menjadi tiga yaitu triangulasi sumber, teknik, dan waktu. Triangulasi sumber dengan cara pengecekan kembali terhadap data temuan dengan data yang data narasumber yang berbeda tetapi dengan data sumber yang sama seperti form wawancara. Triangulasi teknik dengan cara pengecekan data yang didapat dengan melakukan observasi terhadap subjek penelitian. Sedangkan triangulasi waktu yaitu melakukan wawancara terhadap narasumber dengan rentan waktu yang berbeda-beda.

Kedua member check yakni peneliti mengecek data yang diperoleh dari pemberi data. Tujuannya adalah agar informasi yang diperoleh peneliti yang dituliskan pada penelitian sesuai dengan apa yang dimaksud oleh informan. Ketiga perpanjangan pengamatan, sebelumnya peneliti menargetkan penelitian ini selesai tahun 2019 namun akhirnya selesai pada 2020, jadi tahap perpanjangan waktu ini dimanfaatkan untuk melengkapi data-data yang masih kurang.

\section{HASIL PENELITIAN DAN PEMBAHASAN}

Aktivitas sosial dapat ditemui dalam kehidupan sehari-hari, karena manusia beraktivitas, berkegiatan, mempunyai kesibukan yang sangat kompleks sebagai usaha untuk memenuhi kebutuhan hidup manusia itu sendiri (Subiyakto \& Mutiani, 2019). Manusia pada dasarnya adalah makhluk sosial yang memiliki naluri untuk hidup bersama dengan manusia lain. Bertemunya manusia perorangan akan menghasilkan pergaulan hidup dalam kelompok sosial, dalam kelompok sosial akan terjadi interaksi sosial. Interaksi sosial inilah yang membentuk setiap kegiatan atau aktivitas sosial yang dilakukan masyarakat. Sebagaimana yang terjadi dalam aktivitas sosial masyarakat kampung pelangi Banjarbaru yang dapat dijadikan sumber belajar IPS (Mutiani, 2017; Putro et.al., 2019; 
Subiyakto et al., 2021). Peneliti menemukan ada tiga bentuk aktivitas sosial dalam masyarakat kampung pelangi Banjarbaru, Bentuk aktivitas yang dapat dilihat dari hasil penelitian sebagai berikut:

\section{Aktivitas Sosial Masyarakat Kampung Pelangi Banjarbaru Sebagai Sumber Belajar IPS}

\section{a. Kebersihan Lingkungan}

Gotong royong dalam hal kebersihan lingkungan merupakan kegiatan yang langsung diinisiasi oleh kelurahan, dan dinas lingkungan hidup kota Banjarbaru dengan pelayanan kualitas kebersihan lingkungan melalui peran serta masyarakat pada kelompok Sadar Lingkungan Kali Bersih (Darling-Kasih). Gotong royong yang terjadi di sekitar kawasan kampung pelangi kelurahan Guntung Paikat sebagai bentuk Aktivitas sosial menandakan bahwa setiap manusia tidak bisa hidup sendirian. Begitu juga masyarakat di sekitar Kampung Pelangi, mereka harus saling kerja sama dalam setiap kegiatan. Serta harus tetap berinteraksi dengan sesamanya (Putra \& Subiyakto, 2021).

\section{b. Pelatihan Keterampilan Wanita}

Masyarakat kampung pelangi diberikan fasilitas dalam bentuk upaya peningkatan ekonomi keluarga melalui berbagai macam pelatihan oleh tim penggerak PKK Kampung pelangi melalui pelatihan untuk meningkatkan keterampilan wanita. Pelaksanaannya masyarakat diberi penjelasan langsung dari yang memiliki keahlian di bidangnya, setelah mendengar penjelasan masyarakat akan langsung mempraktekkan hasil dari arahan yang diberikan guna memberikan keterampilan secara langsung.

Aktivitas adalah melakukan sesuatu di bawa ke arah perkembangan jasmani dan rohaninya. Pelaksanaan pelatihan tidaklah terlepas dari adanya interaksi antara masyarakat, peran kerjasama dan hubungan yang baik dalam masyarakat itu sendiri sebagaimana yang diungkapkan oleh ibu Husniah (39 Tahun) bahwasannya dalam pelatihan sering diselingi dengan saling bercanda antara masyarakat peserta pelatihan.

\section{c. Bakti Sosial}

Bakti sosial merupakan salah satu aktivitas yang digerakkan oleh tim penggerak PKK Kampung Pelangi dengan menyalurkan bantuan alat sekolah kepada warga belajar di kelompok belajar kampung pelangi. Kegiatan dilaksanakan dengan penyerahan berbagai alat sekolah mulai dari tas, buku, dan berbagai alat tulis yang dalam hal ini secara langsung diserahkan oleh ketua PKK Kota Banjarbaru.

Bentuk bakti sosial yang dilakukan guna meringankan beban orang tua anak yang dirasa kurang mampu sedangkan keinginan belajar anak-anak lumayan tinggi karena anakanak selalu antusias datang ke tempat rumah kelompok belajar, tempat rumah kelompok belajar merupakan sebuah rumah salah satu warga kampung pelangi yang dijadikan tempat untuk pembelajaran baik itu di teras rumah maupun bagian dalam rumah kalau terdapat banyak anak-anak (Subiyakto et al., 2020).

\section{d. Arisan Yasinan}

Kelompok arisan ibu-ibu sudah lama dilaksanakan secara terus menerus oleh masyarakat, sama dengan pernyataan dari ibu Rusmiati bahwa aktivitas arisan sudah berlangsung selama 10 tahun. Aktivitas sosial tidak akan terlepas dari kehidupan masyarakat, karena dari aktivitas sosial seperti kelompok arisan ibu-ibu ini bertujuan untuk menjalin tali silaturahmi antar. Aktivitas sosial juga tidak terlepas dari adanya interaksi antar masyarakat, baik itu secara individu dengan individu maupun individu dengan kelompok. 
Dari adanya aktivitas yang dilaksanakan masyarakat sehingga terbentuknya kesadaran saling menghargai dan menghormati antar masyarakat sehingga terciptanya hubungan sosial yang rukun dan damai (Ayudya \& Rahman, 2019; Mahfuzah et al., 2020; Handy et al, 2020)

Tabel 1.1 Matrik Aktivitas Sosial Masyarakat Kampung Pelangi sebagai Sumber Belajar IPS

\begin{tabular}{|c|c|c|}
\hline Kompetensi Dasar & Materi Pembelajaran & $\begin{array}{c}\text { Aktivitas Sosial Masyarakat Kampung } \\
\text { Pelangi Banjarbaru }\end{array}$ \\
\hline $\begin{array}{l}\text { 3.2 Peserta didik mampu } \\
\text { Menganalisis interaksi } \\
\text { sosial dalam ruang dan } \\
\text { pengaruhnya terhadap } \\
\text { kehidupan sosial, ekonomi } \\
\text { dan budaya dalam nilai dan } \\
\text { norma serta kelembagaan } \\
\text { sosial budaya. }\end{array}$ & $\begin{array}{l}\text { Interaksi sosial: Pengertian, } \\
\text { syarat, dan bentuk } \\
\text { (akomodasi, kerjasama, } \\
\text { asimilasi) }\end{array}$ & $\begin{array}{l}\text { Menjelaskan tentang pengertian dan } \\
\text { syarat terjadinya interaksi sosial. } \\
\text { 1. Individu dengan individu } \\
\text { Interaksi sosial antara individu dengan } \\
\text { individu dalam aktivitas sosial } \\
\text { masyarakat kampung delangi } \\
\text { sangatlah terlihat terutama dapat } \\
\text { terlihat dari aktivitas kebersihan } \\
\text { lingkungan dalam masyarakat } \\
\text { kampung pelangi. } \\
\text { 2. Individu dengan kelompok } \\
\text { Begitu pula Interaksi yang terjadi } \\
\text { antara individu dengan kelompok } \\
\text { dalam aktivitas masyarakat kampung } \\
\text { pelangi dapat dilihat dari interaksi } \\
\text { ketua kelompok arisan dengan } \\
\text { anggotanya, hal tersebut juga terlihat } \\
\text { dari aktivitas pelatihan keterampilan } \\
\text { dalam melakukan pelatihan. } \\
\text { Menjelaskan bentuk interaksi sosial } \\
\text { 1. Kerjasama mentuk interaksi sosial dalam aktivitas } \\
\text { sosial masyarakat kampung pelangi } \\
\text { manjarbaru baru adalah kerjasama yang } \\
\text { mana dalam hal ini masyarakat } \\
\text { melakukan kaksanakan kebersihan lingkungan }\end{array}$ \\
\hline & $\begin{array}{l}\text { Lembaga Sosial: } \\
\text { Pengertian, Jenis, dan Fungsi } \\
\text { (ekonomi, pendidian, } \\
\text { budaya, dan politik) }\end{array}$ & $\begin{array}{l}\text { Menjelaskan tentang jenis dan fungsi } \\
\text { lembaga sosial } \\
\text { 1. Lembaga Agama } \\
\text { Lembaga agama dalam aktivitas sosial } \\
\text { masyarakat kampung pelangi } \\
\text { Banjarbaru terdapat dalam aktivitas } \\
\text { arisan yasinan dimana dalam hal } \\
\text { menjalankan aktivitas sehari-hari }\end{array}$ \\
\hline
\end{tabular}


masyarakat selalu berhubungan dengan tuhannya.

2. Lembaga Ekonomi

Lembaga ekonomi merupakan bagian dari lembaga sosial untuk mengatur hubungan dalam pemenuhan kebutuhan, terlihat dalam aktivitas sosial masyarakat dimana kelompok PKK bertujuan meningkatkan perekonomian masyarakat dengan melakukan pelatihan.

Sumber: Data Diolah (2020)

Pada proses pembelajaran Guru bisa menampilkan materi interaksi sosial (pengertian, syarat dan bentuk) serta dalam materi pembelajaran lembaga sosial (pengertian, jenis, dan fungsi). Mata pelajaran IImu Pengetahun Sosial dengan kurikulum 2013 saat ini menekan pada sumber belajar yang kontekstual. Sumber belajar lokal inilah yang nantinya diajarkan kepada peserta didik. Pembelajaran berbasis konten lokal sangat penting diimplementasikan dalam pembelajaran IPS. Sehingga sumber belajar lokal tersebut dapat dihayati oleh peserta didik. Bukan berarti hanya mendoktrin nilai-nilai yang terkandungnya melainkan dikaji secara kritis, diharapkan peserta didik bisa menyelesaikan masalah di lingkungan nya (Syaharuddin \& Mutiani, 2020).

Aktivitas sosial masyarakat Kampung Pelangi dapat ditampilkan dalam proses pembelajaran, sesuai dengan hasil penelitian ada dua materi pembelajaran yang dapat menggunakan aktivitas sosial masyarakat kampung pelangi Banjarbaru sebagai sumber belajar sebagaimana terlihat dalam tabel 1.1 peserta didik dijelaskan tentang kegiatan interaksi sosial antara masyarakat kampung pelangi yang terjadi dalam kegiatan gotong royong kebersihan lingkungan maupun untuk menolong sesama terdapat interaksi antara individu dengan individu yang artinya kedua belah pihak harus saling merespon, begitu pula dengan interaksi sosial individu dengan kelompok yang terjadi antara ketua kelompok arisan dan pemateri dalam pelatihan keterampilan wanita yang terjadi interaksi, hal ini lah yang dijelaskan kepada peserta didik sebagai sumber belajar (Syaharuddin, et al., 2019).

\section{SIMPULAN}

Aktivitas sosial masyarakat kampung pelangi Banjarbaru sesuai hasil penelitian ada tiga. Pertama arisan dalam bentuk yasinan, yang dilaksanakan dua kali dalam satu minggu pertama pada hari rabu di langgar nurul iman dengan tata cara membaca surah Al-Fatihah, Al-Ikhlas, Al-Falaq dan An-Nas (surah empat) dilanjutkan dengan membaca surah yasin dan diakhiri dengan membaca doa selamat dan yang kedua pada hari minggu di rumah peserta arisan. Kedua gotong royong kebersihan lingkungan dan gotong royong membantu tetangga kalau ada kegiatan. Masyarakat kampung pelangi tidak memiliki jadwal rutin untuk melakukan gotong royong, yang pasti dalam dua bulan sekali melakukan gotong royong melalui program sadar lingkungan kali bersih (darling-kasih) masyarakat langsung membersihkan lingkungannya dan sungai semuning secara inisiatif. Ketiga adalah kegiatan ibu-ibu PKK, kegiatan ini terbagi menjadi dua yaitu pelatihan terhadap ibu-ibu untuk meningkatkan keterampilan dan yang kedua memberikan bantuan kepada masyarakat kampung pelangi. 
Aktivitas sosial masyarakat kampung pelangi dapat dimanfaatkan sebagai sumber belajar IPS untuk mencapai tujuan IPS yaitu menyiapkan peserta didik sebagai warga masyarakat dan warga negara yang baik yang ikut berpartisipasi dalam lingkungan sosialnya. Pada kurikulum 2013 mata pelajaran IPS di SMP dapat memanfaatkan aktivitas sosial masyarakat kampung pelangi sebagai sumber belajar IPS kelas VII semester I yaitu terkait dengan materi interaksi sosial (pengertian, syarat dan bentuk) dan lembaga sosial (pengertian, jenis, dan fungsi). Peserta didik akan mendapatkan informasi yang dekat dengan lingkungannya serta proses pembelajaran dapat bersifat kontekstual sehingga diharapkan dapat memudahkan peserta didik mengenali potensi lingkungannya dan permasalahan yang ada di lingkungannya.

\section{DAFTAR PUSTAKA}

Abbas, E. W., Subiyakto, B., Mutiani, M., Jamaluddin, \& Syahrin, M. A. (2017). Kehidupan Sosial Santri Bataran Sungai Kota Martapura Sebagai Sumber Belajar IPS. Program Studi Pendidikan IP, Fakultas Keguruan dan IImu Pendidikan, Universitas Lambung Mangkurat.

Abbas, E. W. (2018). Penguatan Pendidikan IPS di Tengah Isu-Isu Global. Program Studi Pendidikan IP, Fakultas Keguruan dan Ilmu Pendidikan, Universitas Lambung Mangkurat.

Astuti, L. P. (2011). Pengaruh Pemanfaatan Sumber Belajar dan Motivasi dengan Prestasi Belajar. Universitas Sebelas Maret. https://core.ac.uk/download/pdf/16507434.pdf

Ayudya, D., \& Rahman, A. M. (2019). Bahandil Tradition Community at North Kuin Villages, Banjarmasin. The Innovation of Social Studies Journal, 1(1), 87-93.

Handy, M. R. N., Mutiani, M., Putra, M. A. H., \& Jumriani, J. (2020). The Religious Values in Tradition of Batahlil in Banjar Pahuluan Community. The Kalimantan Social Studies Journal, 2(1), 3947.

Kemendikbud. (2016). Empat Perbaikan Kurikulum 2013. Majalah Jendela Pendidikan dan Kebudayaan, III. jendela.kemendikbud.go.id

Mahfuzah, M., Subiyakto, B., \& Putra, M. A. H. (2020). The Form of Religious Community Activities at Kelayan B as a Learning Resources on Social Studies. The Innovation of Social Studies Journal, 1(2), 150-157.

Mutiani, M. (2017). IPS dan Pendidikan Lingkungan: Urgensi Pengembangan Sikap Kesadaran Lingkungan Peserta Didik. SOSIO-DIDAKTIKA: Social Science Education Journal, 4(1), 45-53. https://doi.org/10.15408/sd.v4i1.5718

Putra, M. A. H. (2019). Building Character Education Through The Civilization Nations Children. The Kalimantan Social Studies Journal, 1(1), 12-17. https://doi.org/10.20527/kss.v1i1.1252

Putra, M. A. H., \& Subiyakto, B. (2021, February). Ecological Awareness Based on Religious Activities. In The 2nd International Conference on Social Sciences Education (ICSSE 2020) (pp. 311-314). Atlantis Press.

Putro, H. P. N., Jumriani, J., Darmawan, D., \& Nuryatin, S. (2020). Social Life of the Community: Perspective of Riverbanks Community in Sungai Jingah, Banjarmasin. The Kalimantan Social Studies Journal, 1(2), 151-158.

Sa'roni, C. (2013). Analisis Potensi Perekonomian Kota Banjarbaru. Jurnal Intekna, 2. ejurnal.poliban.ac.idarticle.view

Setiadi, M. E. (2016). IImu Sosial dan Budaya Dasar. Kencana Prenada Media.

Subiyakto, B., Abbas, E. W., Arisanty, D., Mutiani, M., \& Akmal, H. (2020). Sungai dan Kehidupan Masyarakat Banjar: Penguatan Lokalitas dalam Wacana Pendidikan IPS yang Responsif.

Subiyakto, B., \& Mutiani, M. (2019). INTERNALISASI NILAI PENDIDIKAN MELALUI AKTIVITAS MASYARAKAT SEBAGAI SUMBER BELAJAR ILMU PENGETAHUAN SOSIAL. Khazanah: Jurnal Studi Islam Dan Humaniora, 17(1), 137-166. https://doi.org/10.18592/khazanah.v17i1.2885 
Subiyakto, B., Sari, N. P., Mutiani, M., Faisal, M., \& Rusli, R. (2020). Bonding Social Capital in Social Activities of Urang Banjar in the Martapura Riverbank. The Innovation of Social Studies Journal, 2(1), 17-24.

Subiyakto, B., Syaharuddin, S. \& Mutiani, M. (2018). Nilai Sosial Syaikh Abdurrahman Shiddiq Sebagai Sumber Belajar IPS.

Syaharuddin, S., \& Mutiani, M. (2020). Strategi Pembelajaran IPS: Konsep dan Aplikasi. Program Studi Pendidikan IPS, Fakultas Keguruan dan IImu Pendidikan, Universitas Lambung Mangkurat.

Syaharuddin, S., Rahman, A. M., \& Fitriyani, R. (2019). Utilization Of Social Community as Learning Resources On Social Studies. The Kalimantan Social Studies Journal, 1(1), 18-24.

Sugiyono, S. (2014). Metode Penelitian Kombinasi. Alfabeta. 